\title{
New data on the genus Escaryus Cook et Collins, 1891 (Chilopoda: Geophilomorpha: Schendylidae) from Kazakhstan
}

\author{
Новые данные по геофилам рода Escaryus Cook et Collins, 1891 \\ (Chilopoda: Geophilomorpha: Schendylidae) \\ из Республики Казахстан
}

\author{
Yu.V. Dyachkov ${ }^{1}$, I.H. Tuf ${ }^{2}$ \\ Ю.В. Аьячков ${ }^{1}$, И.Х. Ту $\phi^{2}$
}

\footnotetext{
${ }^{1}$ Altai State University, Lenin Avenue, 61, Barnaul 656049, Russia. E-mail: dyachkov793@mail.ru

${ }^{2}$ Palacký University, Slechtitelu, 27, Olomouc 77900, Czech Republic. E-mail: ivan.tuf@upol.cz

${ }^{1}$ Алтайский государственный университет, проспект Ленина, 61, Барнаул 656049 Россия.
}

\begin{abstract}
KEY WORDS: Geophilomorpha, Schendylidae, faunistics, new records, Kazakhstan.
КЛЮЧЕВЫЕ СЛОВА: Geophilomorpha, Schendylidae, фаунистика, новые локалитеты, Казахстан.
\end{abstract}

ABSTRACT. The genus Escaryus Cook et Collins, 1891 comprises at least 5 species in the Republic of Kazakhstan: E. alatavicus Titova, 1972, E. retusidens Attems, 1904, E. kusnetzowi Lignau, 1929, E. koreanus Takakuwa, 1937 and E. japonicus Attems, 1927, and two undetermined forms: one from the South Kazakhstan Region which seems to be a new species (designated below as Escaryus-1) and the second form is Escaryus sp. from the Kazakh part of the Altai Mts. Both E. koreanus and E. japonicus are new species to the fauna of Kazakhstan. The family Schendylidae, the genus Escaryus and E. kusnetzowi Lignau, 1929 are reported in the South Kazakhstan Region for the first time. Remarks are provided for all species encountered, all being mapped as well. A key to the Escaryus species of Central Asia is given.

How to cite this article: Dyachkov Yu.V., Tuf I.H. 2018. New data on the genus Escaryus Cook et Collins, 1891 (Chilopoda: Geophilomorpha: Schendylidae) from Kazakhstan // Arthropoda Selecta. Vol.27. No.4. P.293-299. doi: 10.15298/arthsel. 27.4.04

РЕЗЮМЕ. Род Escaryus Cook et Collins, 1891 в Республике Казахстан на данный момент включает 5 видов: E. alatavicus Titova, 1972, E. retusidens Attems, 1904, E. kusnetzowi Lignau, 1929, E. koreanus Takakuwa, 1937, E. japonicus Attems, 1927 и две неопределенные формы: одна из Южно-Казахстанской области, которая, по-видимому, является новым видом (обозначена ниже как Escaryus-1) и вторая - Escaryus sp. из казахстанской части Алтая. Два вида E. koreanus и E. japonicus являются новыми для фауны Казахстана. Семейство Schendylidae, род Escaryus и вид E. kusnetzowi Lignau, 1929 впервые отмечены для Южно-Казахстанской области. Для всех видов приведены примечания и картирование находок. Составлен определительный ключ для видов Escaryus Центральной Азии.

\section{Introduction}

The Holarctic genus Escaryus Cook et Collins, 1891 comprises some 33 species [Bonato et al., 2011, 2016], which are mostly associated with mountain regions [Titova, 1972a, b; Pereira, Hoffman, 1993].

The centipede fauna of Kazakhstan is still poorly known. To date, the family Schendylidae was represented in Kazakhstan by Escaryus alatavicus, E. retusidens, E. kusnetzowi and Escaryus sp. [Lignau, 1929; Titova, 1972a, b; Tuf, 2007].

\section{Material and methods}

The studied material was collected in eastern and southern Kazakhstan in 1983, 2001, 2016-2018 (Map). All specimens were collected by hand and preserved in $70 \%$ ethanol.

The pictures have been taken using Axio Cam ERc5s (Zeiss) digital camera attached to a Stemi 2000-C stereomicroscope. The images were prepared using Helicon Focus 6.7.1 software.

The studied material is deposited in the Altai State University (ASU, Barnaul), the Perm State University (PSU, Perm) and the Zoological Museum of the Moscow Lomonosov State University (ZMMU, Moscow) as indicated in the text.

In the systematic part, the standardized terminology proposed by Bonato et al. [2010] is followed. Abbreviations of collectors used in the text are as follows: YD - Yu.V. Dyachkov, AF - A.A. Fomichev, SG S.I. Golovatch, AI - A. Ivanov, AN - A.E. Naydenov, VR - V.V. Rudoi, RY - R.V. Yakovlev. 


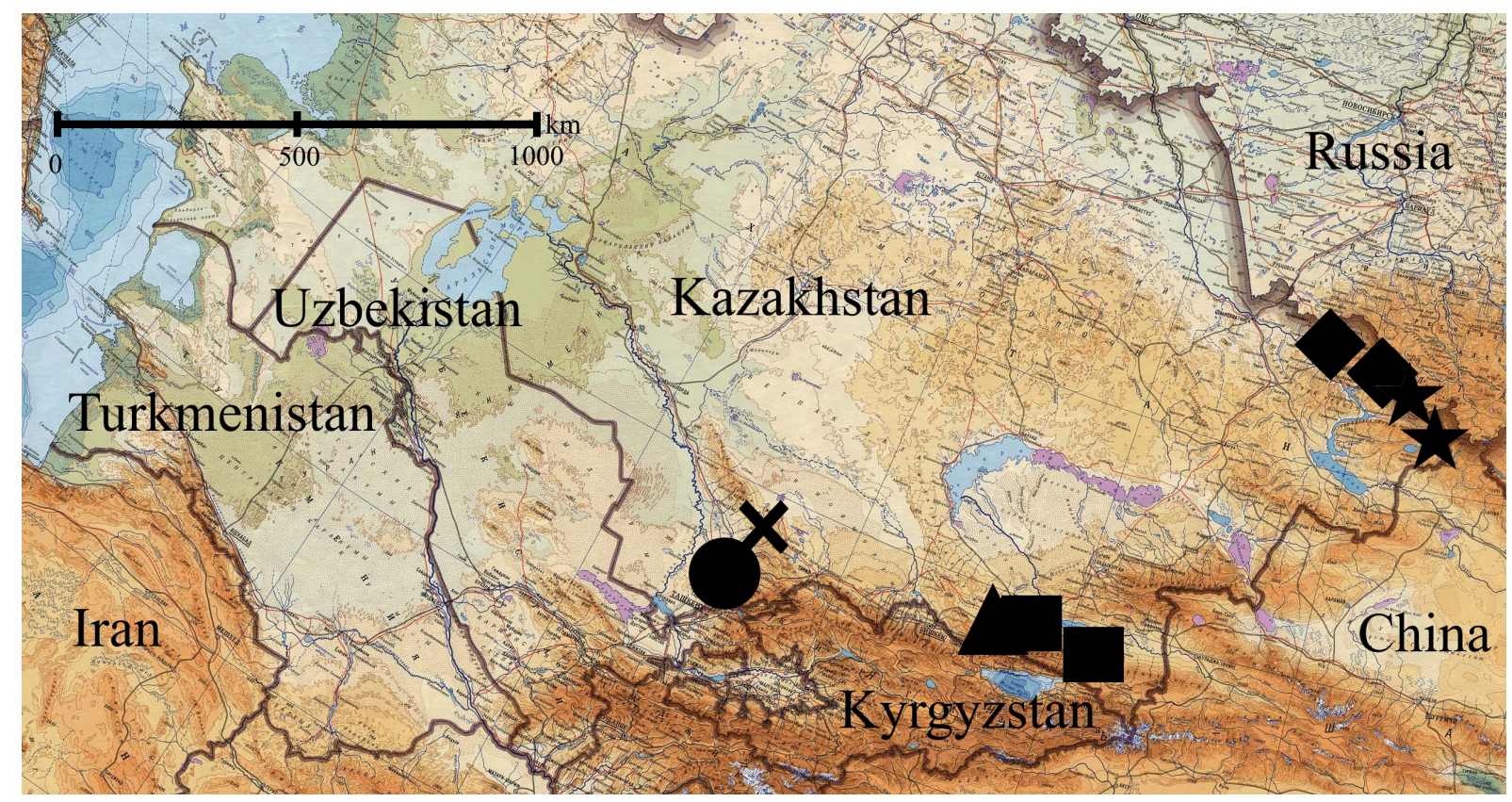

Map. Distribution of Escaryus Cook et Collins, 1891 in Kazakhstan: triangle - Escaryus alatavicus; square — E. retusidens; circle E. kusnetzowi; diamond - E. koreanus; star - E. japonicus; cross - Escaryus-1.

Карта. Распространение Escaryus Cook et Collins, 1891 в Казахстане: треугольник - Escaryus alatavicus; квадрат - E. retusidens; круг - E. kusnetzowi; ромб - E. koreanus; звезда —E. japonicus; крестик — Escaryus-1.

\section{Results}

\section{Family SCHENDYLIDAE Pocock, 1896}

Genus Escaryus Cook et Collins, 1891

Type species: Escaryus phyllophilus Cook et Collins, 1891 (by subsequent designation of Cook [1895]), synonymized later with Escaryus urbicus (Meinert, 1886).

\section{Escaryus alatavicus Titova, 1972 \\ Figs 1-3.}

Escaryus alatavicus Titova, 1972a: 135; 1972b: 105-107, fig. $10(1-4)$.

Type locality: unknown. According to the original description, this species occurs in "Dzhungarian Alatau and
Trans-Ili Alatau" (Almaty Region), but there is no indication of the type locality.

MATERIAL. Almaty Region, Trans-Ili Alatau Mt. Range: 3 $\mathrm{O}^{7} 0^{\top}, 3$ 우 (ASU No 20), Levy Talgar River Valley, Picea forest,

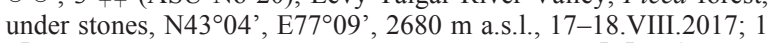
$\sigma^{7}$ (ASU No 105), same place, 17-18.VIII.2017; $3 \mathrm{O}^{7} \mathrm{O}^{7}, 1+1$ juv. (ASU No 21), same place, under stones, $\mathrm{N}^{2} 3^{\circ} 07^{\prime}, \mathrm{E} 77^{\circ} 08^{\prime}, 2180$ m a.s.1., 19.VIII.2017, all YD.

DIAGNOSIS. According to the original description, the body length is $15-20 \mathrm{~mm}$, males have $43-49$; females have 45-49 leg-bearing segments. Labral median arc widely concave and has 14-16 denticles. Ultimate sternite trapeziform with rounded corners. Coxal pores 8-11. Ultimate legs of male incrassate. Anal pores absent.

DISTRIBUTION. Kazakhstan, Almaty Region (Dzhungarian Alatau and Trans-Ili Alatau Mt. Ranges) [Titova, 1972a, b].

REMARKS. The studied specimens are much larger $(23$ to $44 \mathrm{~mm}$ ) and have 49 leg-bearing segments.

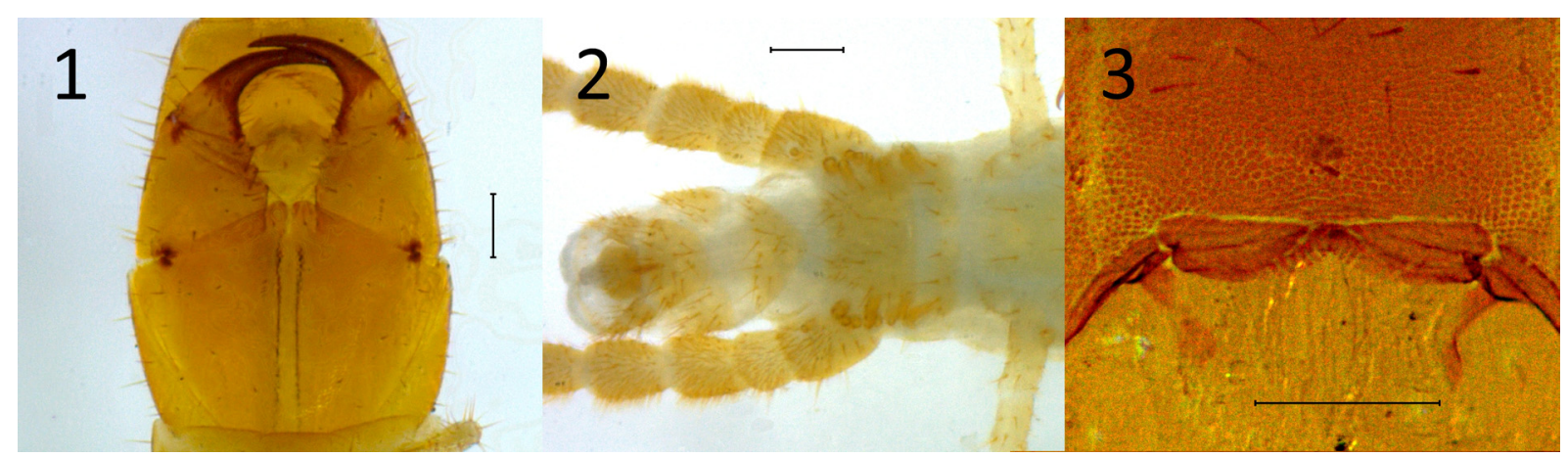

Figs 1-3. Escaryus alatavicus Titova, 1972: 1 - forcipular segment, ventral view; 2 - terminal part of body, ventral view; 3 labrum, ventral view. Scale $0.1 \mathrm{~mm}$.

Рис. 1-3. Escaryus alatavicus Titova, 1972: 1 - ногочелюсть, снизу; 2 - задний конец тела, снизу; 3 - лабрум, снизу. Масштаб 0,1 мм. 


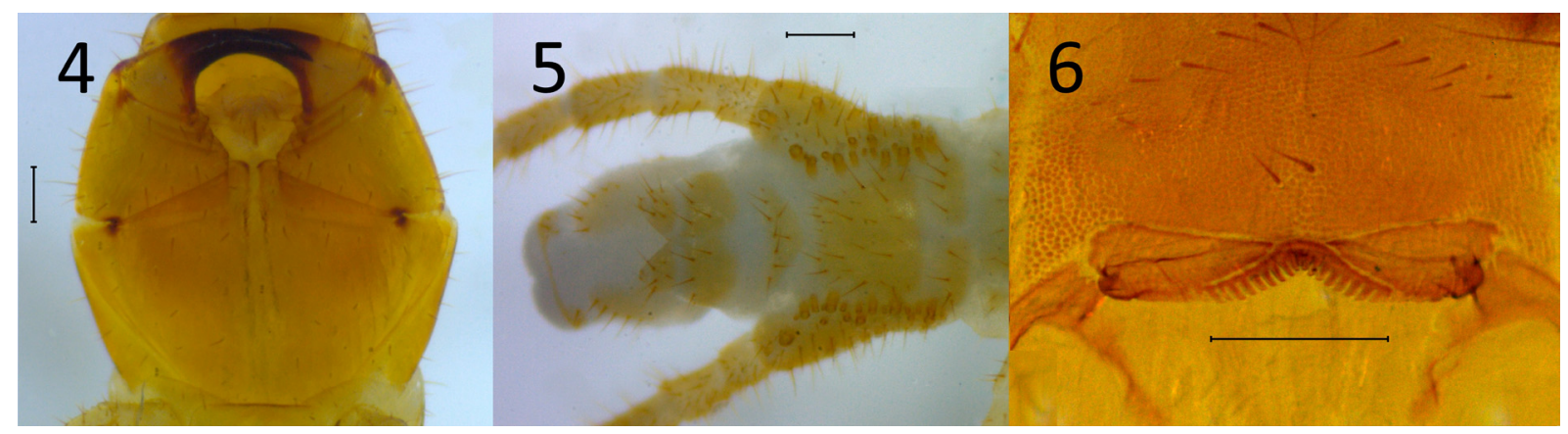

Figs 4-6. Escaryus retusidens Attems, 1904: 4 - forcipular segment, ventral view; 5 - terminal part of body, ventral view; 6 labrum, ventral view. Scale $0.1 \mathrm{~mm}$.

Рис. 4-6. Escaryus retusidens Attems, 1904: 4 - ногочелюсть, снизу; 5 - задний конец тела, снизу; 6 - лабрум, снизу. Масштаб 0,1 мм.

\section{Escaryus retusidens Attems, 1904}

Figs 4-6.

E. retusidens pallidus Folkmanová, 1956: 1635.

Escaryus retusidens Attems, 1904: 121-122, fig. 4-6; Lignau, 1929b: 164-165; Folkmanova, 1956: 1635, fig 1 (3); Titova, 1972a: 135; 1972b: 110-111, fig. 13 (1-5); Pereira, Hoffman, 1993: 9; Volkova, 2016: 675; Nefediev et al., 2017a: 11-13; 2017b: 13; 2017c: 222-223; 2018: 239.

Type locality: "Przewalsk" [now Karakol City in the Issyk-Kul Region of Kyrgyzstan].

MATERIAL. Almaty Region: $1 \sigma^{7}$ (ASU No 22), Trans-Ili Alatau Mt. Range, Levy Talgar River Valley, Picea forest, under

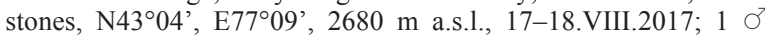

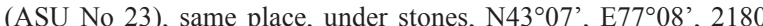
m a.s.1., 19.VIII.2017; 2 ठ $\sigma^{7}$ (ASU No 24), Kungey Alatau Mt. Range, $14.5 \mathrm{~km}$ SW Saty Village, between Kolsay-1 and Kolsay-2 lakes, Picea forest, under stones, N42 ${ }^{\circ} 7^{\prime}$, E78 ${ }^{\circ} 18^{\prime}, 1870 \mathrm{~m}$ a.s.1., 21-22.VIII.2017; 1 ㅇ (ASU No 107), same place, 21-22.VIII.2017, all YD.

DIAGNOSIS. According to Titova [1972b], the body length is to $35 \mathrm{~mm}, 49-55$ leg-bearing segments. Labral median arc widely concave and has 14-18 labral denticles. Ultimate sternite trapeziform. Numerous coxal pores placed lateroventrally. Anal pores absent.

DISTRIBUTION. E. retusidens occurs in Eastern Europe (Moldova and Ukraine) and is also widespread in SW Siberia (Kemerovo Area and Altai Province) and Central Asia (Kazakhstan and Kyrgyzstan) [Titova, 1972a, b; Nefedi- ev et al., 2017a, b, c]. In Kazakhstan it is known from the Almaty Region (Dzhungarian Alatau, Kungey Alatau and Trans-Ili Alatau Mt. Ranges) [Titova, 1972a, b].

REMARKS. The studied specimens have body length to $44 \mathrm{~mm} ; 47,49$, 51 leg-bearing segments (1, 2 and 2 specimens respectively).

\section{Escaryus kusnetzowi Lignau, 1929}

Figs 7-9.

Escaryus kusnetzowi Lignau, 1929a: 205-206, fig. 3-6; Lignau, 1929b: 164; Titova, 1972a: 135; 1972b: 108-110, fig. 12 (1-5).

Type locality: "Telety, am Fl. Dschety-Ogus, beim Issykul-See, und Tumartscha-Brunnen, $108 \mathrm{~km}$ südöstlich vom Balchasch-See“; see Remarks below.

MATERIAL. South Kazakhstan Region, Western Tian-Shan Mts, Ugam Mt. Range, Sayram-Ugam National Park: $3 \sigma^{\top} \sigma^{\top}, 9$ 우 (ASU No 25), Sazanata River Valley, Betula, N4209', E70²4', $1845 \mathrm{~m}$ a.s.1., 19-20.V.2017; $4 \sigma^{7} \sigma^{7}, 13$ of (ASU No 26), same place, N42 ${ }^{\circ} 10^{\prime}, \mathrm{E} 70^{\circ} 25^{\prime}, 1957 \mathrm{~m}$ a.s.1., 3.VI.2017; 1 q (ASU No 106), same place, 3-6.VI.2017, all YD.

DIAGNOSIS. According to Titova [1972b], the body length is to $48 \mathrm{~mm}$, males have 57-65; females have 59-67 leg-bearing segments. Labral median arc widely concave and has 22 labral denticles. Ultimate sternite trapeziform. Numerous coxal pores placed lateroventrally and can be located also at the edge of the ultimate sternite. Ultimate legs of males and females are the same. Anal pores absent.
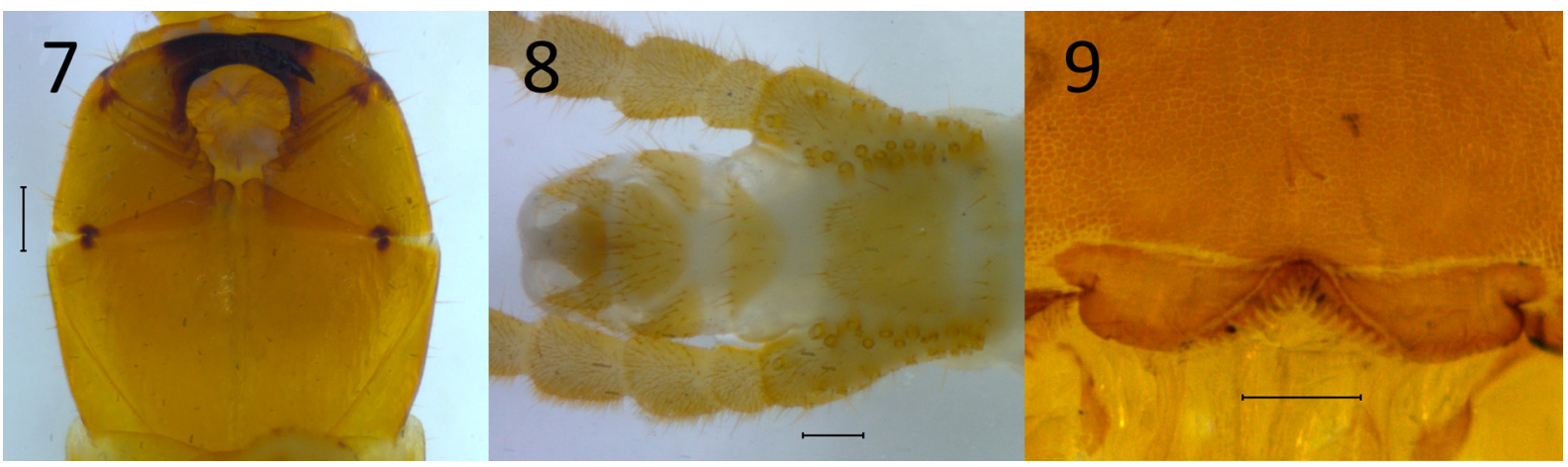

Figs 7-9. Escaryus kusnetzowi Lignau, 1929: 7 - forcipular segment, ventral view; 8 - terminal part of body, ventral view; 9 labrum, ventral view. Scale $0.1 \mathrm{~mm}$.

Рис. 7-9. Escaryus kusnetzowi Lignau, 1929: 7 - ногочелюсть, снизу; 8 - задний конец тела, снизу; 9 - лабрум, снизу. Масштаб 0,1 мм. 


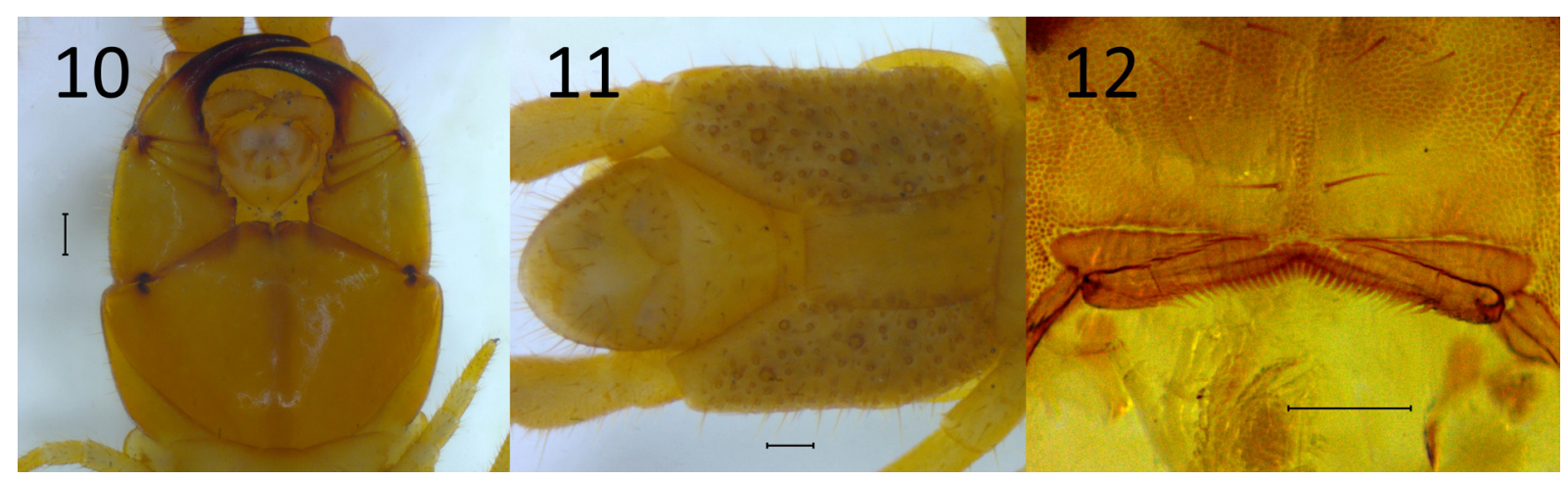

Figs 10-12. Escaryus koreanus Takakuwa, 1937: 10 — forcipular segment, ventral view; 11 — terminal part of body, ventral view; 12 labrum, ventral view. Scale $0.1 \mathrm{~mm}$.

Рис. 10-12. Escaryus koreanus Takakuwa, 1937: 10 - ногочелюсть, снизу; 11 - задний конец тела, снизу; 12 - лабрум, снизу. Масштаб 0,1 мм.

DISTRIBUTION. Kazakhstan: Almaty Region (Dzhungarian Alatau and Trans-Ili Alatau Mt. Ranges) [Lignau, 1929a, b; Titova, 1972a, b] and South Kazakhstan Region (Ugam Mt. Range); Kyrgyzstan: Issik-Kul Region (?).

REMARKS. The studied specimens have the body length

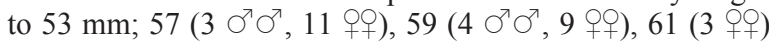
leg-bearing segments. This species is new to the South Kazakhstan Region.

This species has been described by Lignau [1929a] based on 2 specimens; one from "Dschety-Ogus" (village/canyon, environs Karakol City, Issik-Kul Region, Kyrgyzstan) and the other from "Tumartscha" well ["Brunnen"] $108 \mathrm{~km} \mathrm{SE}$ Balkhash Lake (Almaty Region, Kazakhstan). Titova [1972b] suggested the first specimen to be E. retusidens and the second to be E. kusnetzowi, according to the number of legbearing segments -53 and 57 , respectively. Thus, the indication of the type locality becomes ambiguous. Moreover, L.P. Titova [1972b] mentioned the lectotype (sic!) of this species stored in the collections of the A.N. Severtsov Institute of Ecology and Evolution in Moscow, but no such material is placed there (Golovatch, pers. comm.). Titova probably designated a neotype (but not a topotype) from her collection, but without specification of its locality.

Unfortunately Bonato et al. [2016] mentioned "Escaryus kusnetzowi Lignau, 1929" as a nomen nudum without explanation.

\section{Escaryus koreanus Takakuwa, 1937 Figs 10-12.}

Escaryus koreanus Takakuwa, 1937: Titova, 1972a: 135; 1972b: 112-113, fig. 14 (1-5); Pereira, Hoffman, 1993: 9; Nefediev et al., 2017a: 11-13; 2017b: 13; 2017c: 222; 2018: 238.

Terra typica: Korea.

MATERIAL. East Kazakhstan Region: $1 \sigma^{7}$ (ASU No 27), Listvyaga Mt. Range, Bukhtarma River Valley, 6 NNE KatonKaragay Village, scree, under stones, N49¹4', E85³8', $780 \mathrm{~m}$ a.s.1., 1.IX.2016, AF; $2 \sigma^{\top} \sigma^{\top}, 1$ (ZMMU No 7763), same Region, Ubinsky Mt. Range, $\sim 55 \mathrm{~km}$ SE from Ust-Kamenogorsk City, Zimovie Village, Abies and Populus forest, soil and litter, 22.VI. 1983, SG.

DIAGNOSIS. According to Titova [1972b], the body length is to $65 \mathrm{~mm}, 45-53$ leg-bearing segments. Labral median arc slightly concave and has 2 kinds of labral denticles: middle ones obtuse and lateral ones pointed. Ultimate sternite rectangular. Coxopleura covered with numerous small pores and an extra pair of large pores. Anal pores small.
DISTRIBUTION. Korea [Takakuwa, 1937]. Japan [Takakuwa, 1940]. Russia: Western Siberia (Kemerovo Area, Altais and Tomsk Area), Eastern Siberia (Krasnoyarsk Province) and Russian Far East (the Maritime Province and Cisamuria) [Titova, 1972a, b; Rybalov, 2002; Vorobiova et al., 2002; Nefediev et al., 2017c]. Kazakhstan (East Kazakhstan Region).

REMARKS. The studied specimens have 53 leg-bearing segments. This species is new to the fauna of Kazakhstan.

\section{Escaryus japonicus Attems, 1927} Figs 13-15.

Escaryus japonicus Attems, 1927: Takakuwa, 1935: 47; 1940: 35-36, figs 27-29; Byzova, Chadaeva, 1965: 337; Titova, 1972a: 135; 1972b: 113-114, fig. 15 (1-4); Pereira, Hoffman, 1993: 9; Farzalieva, 2008: 67-69; Nefediev et al., 2017a: 11; 2017c: 222.

Type locality: "Todohokhe. Hohango", Japan.

MATERIAL. 1 ণ , 1 (PSU), East Kazakhstan Region, Altai Mts, Tarbagatai Mt. Range, Burkhat pass, 15-17.VI.2001, AI; 4 $\sigma^{7} \sigma^{7}, 3$ 90 (ASU No 86), same Mts, Listvyaga Mt. Range, near Aksharbakh, Village, N49³2', E85³2', $1400 \mathrm{~m}$ a.s.1., 3-5.VII. 2018, RY, VR, AN; 1 fragm. (ASU No 108), same place, 3-5.VII. 2018, RY, VR, AN.

DIAGNOSIS. According to Titova [1972b], a large schendylid (up to $43 \mathrm{~mm}$ ), 51 leg-bearing segments. Labral median arc slightly concave, all labral denticles are obtuse. Ultimate sternite rectangular. Coxopleura with numerous pores, all pores of the same size. Ultimate legs of male incrassate, female with slender ones. Anal pores present.

DISTRIBUTION. Japan [Attems, 1927]. Northern China [Takakuwa, Takashima, 1949]. Widespread from the Urals and the middle Volga Region (Russia) to the Russian Far East through Siberia [Byzova, Chadaeva, 1965; Titova, 1972a; Farzalieva, 2008; Volkova, 2016; Nefediev et al., 2017a]. Kazakhstan (East Kazakhstan Region).

REMARKS. According to Titova [1972b], E. japonicus has 51 leg-bearing segments (Tab. 2), according to Takakuwa $[1935,1940]$, this species has 47, 51, 55 leg-bearing segments. The studied specimens have 43 ( $1 \sigma^{7}, 1$ \%, PSU), $47\left(2 \sigma^{\top}, 1+\right), 49\left(1 \sigma^{\top}, 2\right.$ 9 ) and 51 ( $\sigma^{\top}, 1$ fragm. all ASU) leg-bearing segments. All other features (such as the structure of labral denticles, the shapes of both ultimate sternite and ultimate legs; Figs 13-15) are similar to Titova's description. Thus, we consider these specimens as $E$. japonicus. This species is new to the fauna of Kazakhstan. 

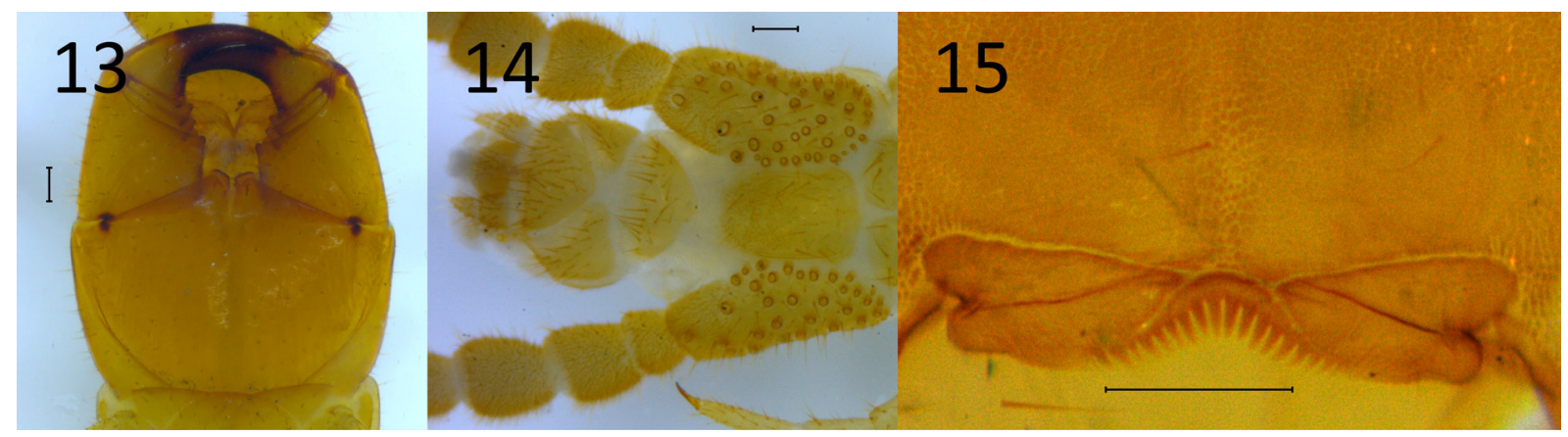

Figs 13-15. Escaryus japonicus Attems, 1927: 13 - forcipular segment, ventral view; 14 - terminal part of body, ventral view; 15 labrum, ventral view. Scale $0.1 \mathrm{~mm}$.

Рис. 13-15. Escaryus japonicus Attems, 1927: 13 - ногочелюсть, снизу; 14 - задний конец тела, снизу; 15 — лабрум, снизу. Масштаб 0,1 мм.

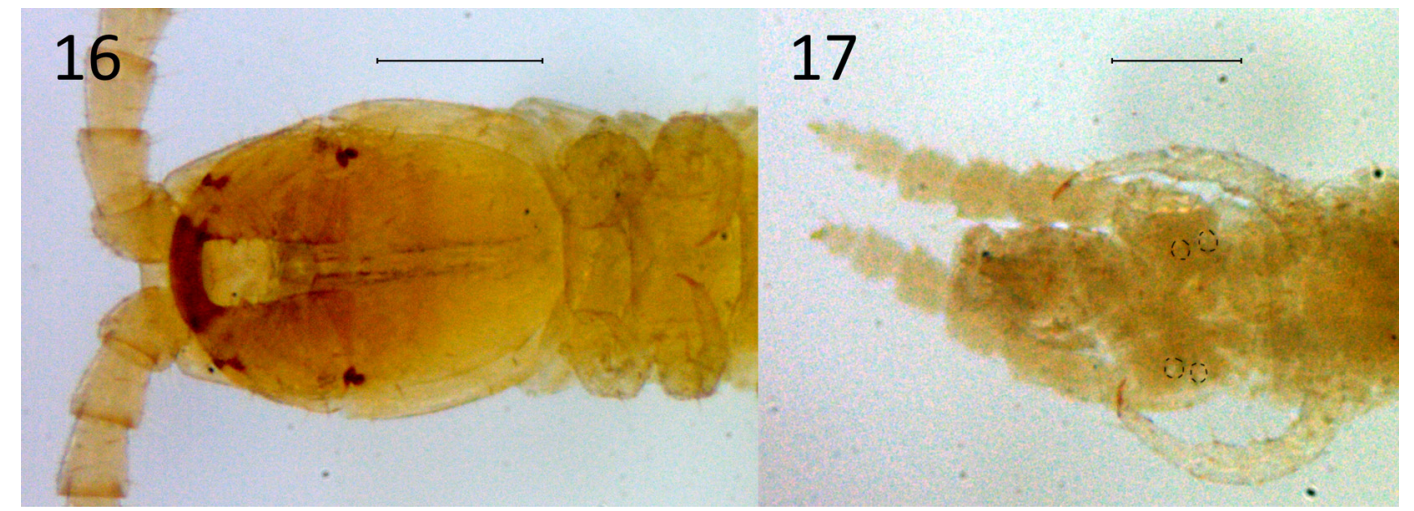

Fig 16-17. Escaryus-1: 16 - forcipular segment, ventral view; 17 - terminal part of body ventral view. Scale $0.1 \mathrm{~mm}$. Рис. 16-17. Escaryus-1: 16 - ногочелюсть, снизу; 17 - задний конец тела, снизу. Масштаб 0,1 мм.

\section{Escaryus-1}

Figs 16-17.

Type locality: Karatau Mt. Range (South-Kazakhstan Region).

MATERIAL. South Kazakhstan Region, Karatau Mt. Range: 36 juv. (ZMMU No 7758), Aktas Village, in soil, 0-10 cm, 14.V. 1974; 6 juv. (ZMMU No 7759), Aktas Village, slope of mountain, Crataegus and Malus forest, in soil, 12.V.1974.

DIAGNOSIS. The body length is to $11 \mathrm{~mm}, 43 \mathrm{leg}$ bearing segments. Ultimate sternite trapeziform with rounded corners. Coxal pores 2. Basal denticle on forcipular tarsungulum well-developed.

REMARKS. Material is in poor condition. This form is seems to be particularly similar to E. chadaevae Titova, 1972 from Western Siberia (Kemerovo Area and Altai Republic) [Titova, 1972b]. The latter species has 33-35 legbearing segments and 5-7 coxal pores, whereas the studied specimens have 43 leg-bearing segments and 2 pores (juvenile condition?). Escaryus-1 is also similar to E. latzeli (Sseliwanoff, 1881) from the eastern Tian-Shan (41 or 43 legbearing segments and 9-12 coxal pores) [Sseliwanoff, 1881].

\section{Conclusions}

The genus Escaryus in the fauna of Kazakhstan presently comprises at least 5 species: $E$. alatavicus, $E$. retusidens, E. kusnetzowi, E. koreanus and E. japonicus and two undetermined forms: Escaryus-1 from the South Kazakhstan Region which seems to be one more species but adult specimens should be studied to determine the taxonomic status of this form; Escaryus sp. from the Kazakh part of the Altai Mts.

Three species are known from the Almaty Region: E. alatavicus, E. kusnetzowi (Dzhungarian Alatau and Trans-Ili Alatau Mt. Ranges) and E. retusidens (Dzhungarian Alatau, Kungey Alatau and Trans-Ili Alatau Mt. Ranges); E. kusnetzowi is also recorded from the South Kazakhstan Region (Ugam Mt. Range). Two species are known from the East Kazakhstan Region (Altai Mts): E. japonicus (Tarbagatai and Listvyaga Mt. Ranges) and E. koreanus (Listvyaga and Ubinsky Mt. Ranges).

According to Titova [1972b], the studied species constitute 2 groups of similar species in the Kazakhstan fauna: with trapeziform (E. alatavicus, E. kusnetzowi and $E$. retusidens) and rectangular-shaped ( $E$. japonicus and $E$. koreanus) ultimate sternites. The first group members (with trapeziform ultimate sternite) have also a similar number of labral denticles: $14-16$ in $E$. alatavicus, $14-18$ in E. retusidens and 22 in E. kusnetzowi. The main differences between these species are 
Table 1. Differences between Escaryus alatavicus Titova, 1972, E. kusnetzowi Lignau, 1929, E. retusidens Attems, 1904

and Escaryus-1.

Таблица 1. Различия между Escaryus alatavicus Titova, 1972, E. kusnetzowi Lignau, 1929, E. retusidens Attems, 1904 и Escaryus-1.

\begin{tabular}{|c|c|c|c|c|}
\hline Species & E. alatavicus & E. kusnetzowi & E.retusidens & Escaryus-1 \\
\hline size of body, mm & from 15-20 to 23-44 & up to 53 & up to 44 & to 11 \\
\hline leg-bearing segments & $\begin{array}{c}45-47 \\
\text { (rarely 43, 49) }\end{array}$ & $\begin{array}{c}57-63 \\
\text { (rarely 65, 67) }\end{array}$ & $\begin{array}{c}49 \\
\text { (rarely 47, 51, 53, 55) }\end{array}$ & 43 \\
\hline $\begin{array}{c}\text { number of labral } \\
\text { denticles }\end{array}$ & $14-16$ & 22 & $14-18$ & $?$ \\
\hline ultimate sternite & trapeziform & trapeziform & trapeziform & trapeziform \\
\hline $\begin{array}{c}\text { number of coxal } \\
\text { pores }\end{array}$ & $8-11$ & numerous & numerous & 2 \\
\hline anal pores & absent & absent & absent & $?$ \\
\hline
\end{tabular}

Table 2. Differences between Escaryus koreanus Takakuwa, 1937 and Escaryus japonicus Attems, 1927. Таблица 2. Различия между Escaryus koreanus Takakuwa, 1937 и Escaryus japonicus Attems, 1927.

\begin{tabular}{|c|c|c|}
\hline Species & E. koreanus & E.japonicus \\
\hline size of body, mm & $55-65$ & up to 43 \\
\hline leg-bearing segments & $47-53$ (rarely 45-49) & 51 (rarely 43, 47, 49,55) \\
\hline $\begin{array}{c}\text { number and structure of } \\
\text { labral denticles }\end{array}$ & $\begin{array}{c}\text { middle denticles are obtuse, lateral } \\
\text { denticles are pointed }\end{array}$ & all denticles are obtuse \\
\hline ultimate sternite & rectangular long and narrow & rectangular long and narrow \\
\hline anal pores & small & present \\
\hline
\end{tabular}

the body size and the number of leg-bearing segments (Tab. 1). The second group members have a rectangular-shaped ultimate sternite; the main differences between these species are the number of leg-bearing segments and the structure of labral denticles (Tab. 2).

Key to the Escaryus Cook et Collins, 1891 species From CENTRAl ASIA

1. Ultimate sternite rectangular .... 2

- Ultimate sternite trapeziform pointed.............Escaryus koreanus Takakuwa, 1937

- All denticles are obtuse Escaryus japonicus Attems, 1927

3. Body size up to $11 \mathrm{~mm}, 43$ leg-bearing segments, 2 coxal pores ............................................................ Escaryus -1

- Number of coxal pores more than 2 .............................. 4

4. Body size 9-15 mm, coxal pores 5-7Escaryus chadaevae Titova, 1972

- Number of coxal pores more than 7 , body size up to 20 $\mathrm{mm}$

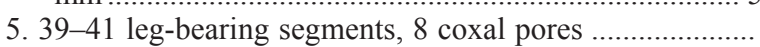
Escaryus kirgizicus Titova, 1972

- More than 43 leg-bearing segments, coxal pores 8 or more

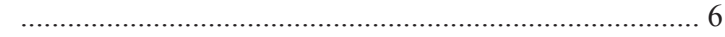

6. 8-12 coxal pores, 45-47 (rarely 43, 49) leg-bearing segments ...................... Escaryus alatavicus Titova, 1972

- 9 or more coxal pores, body size $22-32 \mathrm{~mm}$................... 7

7. 41-43 leg-bearing segments, 9-12 coxal pores ................ ........................... Escaryus latzeli (Sseliwanoff, 1881)

- Numerous coxal pores Escaryus latzeli (Sseliwanoff, 1881)

8. 35-41 leg-bearing segments

Escaryus oligopus Attems, 1904
- More than 47 leg-bearing segments ................................. 9 9. 49 (rarely 47, 51, 53, 55) leg-bearing segments ............. ............................ Escaryus retusidens Attems, 1904 - 61-63 (rarely 57, 59, 65, 67) leg-bearing segments .......... ........................... Escaryus kusnetzowi Lignau, 1929

Acknowledgments. S.I. Golovatch (Moscow, Russia) kindly edited the English of an advanced draft. The first author wishes to thank R.V. Yakovlev (Barnaul, Russia) and I.I. Temreshev (Almaty, Kazakhstan), D.F. Shovkoon (Samara, Russia) and S.V. Kornev (Orenburg, Russia) for the help in organization of the field trips to Tian-Shan Mountains in 2017. My sincerest thanks are also due administration and the scientific department of the Sayram-Ugam National Park (Shymkent, Kazakhstan) and of the Kolsay Lakes National Park (Saty, Kazakhstan) for their assistance and contribution in our field works. Special thanks go to A.A. Fomichev and G.Sh. Farzalieva, R.V. Yakovlev, A.E. Naydenov and V.V. Rudoi who donated material for current study. I am grateful to the curator of myriapod collection in ZMMU A.A. Schileyko (Moscow, Russia) for his help in preparing of this paper. Also I wish to thank the director of the Tigirek Nature Reserve, P.V. Golyakov and his employees, E.A. Davydov and D.V. Kuzmenkin (all from Barnaul, Russia) for providing me with the facilities. This study was supported in part by the grant No. 6.2884.2017/4.6 given by the Ministry of Education and Science of the Russian Federation and was partly supported by project on Faculty of Science of Palacký University Olomouc, No. PrF_2018_020.

\section{References}

Attems C. 1927. Neue Chilopoden // Zoologischer Anzeiger. Bd.72. P.291-305. 
Bonato L., Chagas Junior A., Edgecombe G.D. Lewis J.G.E., Minelli A., Pereira L.A., Shelley R.M., Stoev P., Zapparoli M. 2016. ChiloBase 2.0 - A World Catalogue of Centipedes (Chilopoda). Available at http://chilobase.biologia.unipd.it.

Bonato L., Edgecombe G.D., Lewis J.G., Minelli A., Pereira L.A., Shelley R.M., Zapparoli M. 2010. A common terminology for the external anatomy of centipedes (Chilopoda) // ZooKeys. Vol.69. P.17-51

Bonato L., Edgecombe G.D., Zapparoli M. 2011. [ChilopodaTaxonomic overview] // A. Minelli (ed.). Treatise on Zoology - Anatomy, Taxonomy, Biology. The Myriapoda. Vol.1. Brill, Leiden-Boston. P. 408-443.

Bonato L., Minelli A. 2014. Chilopoda Geophilomorpha of Europe: a revised list of species with taxonomic and nomenclatural notes // Zootaxa. Vol.3770. No.1. P.1-136.

Byzova Yu.B., Chadaeva Z.V. 1965. [A comparative characteristic of the soil fauna of various associations in an Abies sibirica forest (Kemerovo Area)] // Zoologicheskii Zhurnal. Vol.44. No.3. P.331-339 [in Russian, with English summary].

Cook O.F. 1895. An arrangement of the Geophilidae, a family of Chilopoda // Proceedings of the United States National Museum. Vol.18. P.63-75.

Farzalieva G.Sh. 2008. [The fauna and chorology of Myriapoda from the Urals and Cisuralia]. Thesis of Candidate (Ph.D.) of Biological Sci. Degree. Perm State University. 189 p. [in Russian]

Folkmanova B. 1956. [On new forms of the order Geophilomorpha from the South Regions of the USSR] // Zoologicheskii Zhurnal. Vol.35. No.11. P.1633-1646 [in Russian].

Lignau N.G. 1929a. Neue Myriopoden aus Zantralasien // Zoologischer Anzeiger. Bd.85. H.9/10. P.205-217.

Lignau N.G. 1929b. Zur Kenntnis der zentralasiatischen Myriopoden // Zoologischer Anzeiger. Bd.58. P.159-175.

Nefediev P.S., Tuf I.H., Farzalieva G.Sh. 2017a. Centipedes from urban areas in southwestern Siberia, Russia (Chilopoda). Part 2. Geophilomorpha // Arthropoda Selecta. Vol.26. No.1. P.8-14.

Nefediev P.S., Farzalieva G.Sh., Tuf I.H., Nedoev H.Kh., Niyazov S.T. 2017b. Millipede and centipede assemblages on the northern and southern slopes of the lowland Altais, southwestern Siberia, Russia (Diplopoda, Chilopoda) // Tropical Natural History. Suppl.5. 17th International Congress of Myriapodology. 23-26 July 2017, Krabi, Thailand. Book of abstracts. P.13.

Nefediev P.S., Farzalieva G.Sh., Tuf I.H. 2017c. A preliminary review of the centipede fauna of the Altai State Nature Biosphere Reserve, southwestern Siberia, Russia (Chilopoda: Lithobiomorpha, Geophilomorpha) // Arthropoda Selecta. Vol.26. No.3. P.217-224.

Nefediev P.S., Farzalieva G.Sh., Tuf I.H., Nedoev Kh.Kh., Niyazov S.T. 2018. Millipede and centipede assemblages on the northern and southern slopes of the lowland Altais, southwestern Siberia, Russia (Diplopoda, Chilopoda) // ZooKeys. Vol.741. P.219-254.
Pereira L.A., Hoffman R.L. 1993. The American species of Escary$u s$, a genus of Holarctic centipedes (Geophilomorpha: Schendylidae) // Jeffersoniana. Vol.3. P.1-72.

Rybalov L.B. 2002. [Zonal and landscape changes in soil invertebrate populations in a near-Yenisei River region of middle Siberia and the role of temperature adaptations in the meridional (zonal) distribution of invertebrates] // Russian Entomological Journal. Vol.11. No.1. P.77-86 [in Russian, with English summary].

Sseliwanoff A.V. 1881. [Geophilidae from the Museum of Imperial Academy of Sciences] // Zapiski Imperatorskoi Akademii Nauk. Vol.40. P.1-27 [in Russian].

Takakuwa Y. 1935. Über japanische Escaryus-Arten // Transactions of the Sapporo Natural History Society. Vol.14. No.1. P.46-50.

Takakuwa Y. 1937. Eine neue Escaryus-Art aus Korea // Zoological Magazine. Vol.49. P.297-299.

Takakuwa Y. 1940. Geophilomorpha, Class Chilopoda, Epimorpha // Fauna Nipponica. Vol.9. Fasc.8. No.1. Tokyo: Sanseido Book Store. 156 pp. [in Japanese]

Takakuwa Y., Takashima H. 1949. Myriapods collected in Shansi, North China // Acta Arachnologica. Vol.11. No.1-2. P.51-69 [in Japanese, with English summary].

Titova L.P. 1972a. [Pattern of the distribution of the genus Escaryus (Chilopoda) in the USSR] // M.S. Ghilarov (ed.). Problemy pochvennoi zoologii. Materials of the 4th All-Union Conference. Baku, 1972. Moscow: Nauka Publ. P.135-136 [in Russian].

Titova L.P. 1972b. [New species of the genus Escaryus Cook et Collins (Schendylidae, Chilopoda)] // M.S. Ghilarov (ed.). Ekologiya pochvennykh bespozvonochnykh. Moscow: Nauka Publ. P.94-119 [in Russian].

Tuf I.H. 2007. [Diversity of selected taxa of invertebrates in the Altai (East Kazakhstan)] // Modern approaches to biodiversity protection in the context of steady development achievement of the Republic of Kazakhstan. Materials of International Kazakh-Czech Scientific Conference, Ust-Kamenogorsk, 2007. P.56-64. [in Czech, summary in English]

Volkova Yu.S. 2016. [An annotated catalogue of geophilomorph centipedes (Chilopoda, Geophilomorpha) from the European part of Russia] // Zoologicheskii Zhurnal. T.95. No.6. P.669678 [in Russian, with English summary].

Vorobiova I.G., Rybalov L.B., Rossolimo T.E., Zalesskaja N.T. 2002. [Zonal and landscape distribution of the myriapod fauna and populations (Myriapoda) in the Yenisei River basin] // Izuchenie, sokhranenie i vosstanovlenie bioraznoobraziya ekosistem na Yeniseiskom ekologicheskom transekte: Zhivotnyi mir, etno-ekologicheskie issledovniya, 2. Moscow: IPEE RAN Publ. P.60-71 [in Russian].

Responsible editor S.I. Golovatch 